\section{The Making of the Modern Jewish Bible: How Scholars in Germany, Israel, and America Trans- formed an Ancient Text, by Alan T. Levenson}

Lanham, Maryland: Rowman \& Littlefield Publishers, Inc., 20I I xiii + 247 pages | ISBN: 978-I-4422-05I6-I (hardback) $\$ 49.95$

Alan T. Levenson's The Making of the Modern Jewish Bible: How Scholars in Germany, Israel, and America Transformed an Ancient Text provides-through a synthesis of cultural history, biblical scholarship, and modern Jewish history — an examination of how the meaning of the Hebrew Bible has been socially constructed, thereby offering not only a descriptive history of Jewish Bible scholarship but also a presentation of how Jews in the last four centuries have both related to and hence reconstructed the Bible and its place within their lives. In this way, his is something of a Jewish studies reorientation of Jonathan Sheehan's 2005 The Enlightenment Bible: Translation, Scholarship, Culture, an examination of Protestant translators and scholars from the seventeenth and eighteenth century, and their transformation of the Bible from a book justified by theology, to a book justified by culture. Where the scope of Levenson's presentation differs from Sheehan's is in its wider historical focus, examining as it does scholarship ranging from the (Jewish) Enlightenment until the present day. Moreover Sheehan, as a cultural historian, is not interested in his presentation of how the biblical narrative might have been reconceived from a postmodern perspective: this is where Levenson's study comes into its own. The author's programme is obviously related to recent "reader-response" approaches to Biblical criticism (in which the biblical meaning determined by the contemporary reader is privileged over traditional historical-critical concerns), and indeed, Levenson himself notes that his is a presentation which might better be considered under the rubric of a "postmodern" analysis than that of the "modern" which his title might otherwise suggest (6).

The first chapter essentially attempts to reclaim Baruch Spinoza for Judaism in general, and as a Jewish Bible critic in particular: thus in Levenson's presentation, Spinoza becomes the methodological precursor of the various techniques which were to become inherent to modern historical-critical biblical scholarship, and so to the scholars assessed in the following pages 
(15-16). After this brief excursus, the presentation begins proper and so Levenson moves confidently through three centuries and three continents of scholarship. Part I looks at the German Jewish thinkers of the Haskalah, the Jewish Enlightenment: the author examines the German-language Bible translations of Moses Mendelssohn (Ch. 2), Samson Raphael Hirsch (ch. 3), Benno Jacob (ch. 4), and the Martin Buber, Franz Rosenzweig collaboration (ch. 5), thereby interacting with aspects of Jewish tradition encompassing Reform and Orthodox perspectives. Indeed, despite the denominational diversity which informed each of these translation projects, nevertheless Levenson is able to provide an encompassing conclusion: each translation was ultimately underpinned by a religious humanism typical of the German-Jewish experience - the striving to be fully modern, both German and Jew-and that this was the governing factor which provoked the Haskalah thinkers to produce these first attempts at a modern Jewish Bible.

Part 2 moves from Germany to the Israel of the early Zionists, exploring the scholarship of Ahad Haam (ch. 6), David Ben-Gurion (ch. 7), and Nehama Leibowitz (ch. 8). Once again, though affirming the diversity of the various approaches utilized by these scholars, Levenson is even so able to determine the operative intent of all this scholarly ferment: to make a Bible for a modern nation; and to make a modern nation from the Bible. Throughout, then, Levenson is conscious of the ideological assumptions and biases which may have informed the subjects of his study in their attempt to read the Bible as a document central to Israeli statehood. Finally in part 3 Levenson reaches America in the programmatically entitled "The Flowering of Jewish Bible Studies in North America": the author sees in this recent scholarship the conclusion of a programme first begun with Spinoza, and so the creation of a fully Jewish biblical scholarship. Beginning in 1966 with Nahum Sarna's Understanding Genesis, the author thus affirms this work to be the turning-point in the creation of a modern Jewish Bible; this (along with the work of Robert Alter) is treated in chapter 9 before moving in chapter 10 to the modern American congregational chumah: Torah and commentaries in which Levenson believes we see the full articulation of a completely Jewish biblical scholarship, phenomena which—through Levenson's diachronic presentation-are, then, the culmination of all these scholarly efforts.

The methodological incongruity in Levenson's presentation - treating as it does Bible translations when considering the scholarly contributions of German Jewry, before moving to Bible scholarship in a more general sense when reviewing that of Israel and America-is somewhat mitigated by Leven- 
son's masterful handling of his sources, of which throughout the author seems confidently in control. Indeed, the book is essentially a synthesis of and heavily indebted to other works of scholarship: there is little which is new in his presentation. Thus his argument that Spinoza must be reclaimed as the first modern Jewish Bible critic strongly resembles the similar siren call of Seth L. Sanders in the first chapter of his 2009 monograph The Invention of Hebrew, and which sets up a comparable observation. Sanders argues that Spinoza-along with Thomas Hobbes - in treating the Bible as a historically relativized product of its own time thereby opened it up to subsequent historical-critical attempts ( $13-35$ ). Moreover, Keith W. Whitelam provided already in 1996 an attempt to map the subjective influence of contemporary politics in shaping a biblical exegete's construction of the Israelite past (The Invention of Ancient Israel: The Silencing of Palestinian History). Indeed, the general assumption of the treatment - that Jewish Bible scholarship must be examined as a creative response to the needs of Western culture and Jewish nationalism-seems an observation analogous to that which has informed the writings of the Modern Hebrew literary critic Alan Mintz, who has characterized Jewish literary ferment as essentially Responsa to shifts in traditional modes of perception. Thus, in Hurban: Responses to Catastrophe in Hebrew Literature (1996), Mintz makes the claim that Jewish society

has had many massive national catastrophes visited upon it and still survived; and in each case the reconstruction was undertaken in significant measure by the exertions of the Hebrew literary imagination, as expressed in prophecy, liturgy, exegesis, and poetry. (x)

Nevertheless, this debt to previous scholarship is something which Levenson readily acknowledges: "this book is not an original piece of scholarship: I have merely tried to translate the findings of the academy for a wider audience" (5) - and what is indeed unique about this work is its clear presentation of the academic output of groups of Jewish Bible scholars who have never before been examined together. Such a synthesis provides new opportunities to trace scholarly continuities between academic trends (so the debt of Israeli scholarship to that of the German Haskalah is here made explicit), and ultimately serves to situate the American academia which Levenson determines to be the fullest articulation of Jewish biblical scholarship not only within antecedent Jewish scholasticism, but also within the larger trends of 
the Academy as a whole (thereby Alter is treated in relation to the Copenhagen and Sheffield Schools of biblical minimalism).

Contextualizing these Jewish approaches to larger scholarly trends is a valuable consideration, however it should be noted that the author's crucial aim here is to ask what is distinctively "Jewish" about them. His central premise is that Jews speak in a shared idiom about the Bible and that this can be traced in modern biblical scholarship, starting with Spinoza and concluding in contemporary America. Thus he sums up in his concluding chapter the four commonalities which underpin the modern Jewish Bible: I) polemic and apologetic; 2) inclusion of rabbinic interpretation in its exegetics; 3) always affirming the pre-eminence of the Hebrew text; and, despite these common features, 4) ultimately pluriform in nature. This seems a somewhat tidy solution to the particularities of the vast literature which Levenson surveys, spanning as this does three centuries and across three continents. The author approaches this mass of materials in such an (arguably reductionist) way in order to develop a clear chronology of the scholarship from which to posit his hypothesis concerning the diachronic development of Jewish approaches to the biblical data, thus he plots a trajectory which concludes in contemporary America. Certainly this provides a compelling and highly readable narrative. The book is clearly written and, though certainly aimed a scholarly audience, the organisation of the presentation and clarity of prose means that this work is nevertheless accessible also to the interested lay-person. (Indeed, in my close reading of the text, I only noticed one minor typographical error: Levenson systematically refers to the "Scheffield School" when discussing the "Sheffield School" of biblical minimalism-which demonstrates a lack of familiarity with scholarship from the University of Sheffield behind his claim that there is "anti-Israel sentiment" at "Scheffield" [sic; 202]). However, in providing such a cogent outline, at times the author's central premise-that of the essential "Jewishness" of all these scholarly approaches-is somewhat obscured. Levenson begins his study by noting that

when it comes to Bible study, purely disciplinary considerations (Is one a source critic? A form critic? A rhetorical critic? A canonical critic?) or ideological considerations (Is one a feminist? A secularist? A liberation theologian?) prove to be the controlling factors. (4)

Yet what can be especially "Jewish" about any of these governing methodological decisions (as opposed to critics who practice their art utilizing the same 
tools but beginning from the position of another ideology, such as scholars who come from Protestant or secular backgrounds) is not returned to. The four criteria with which he characterizes modern Jewish Bible scholarship may very well refer to biblical scholarship in a wider sense, and not in any explicitly "Jewish" crystallization. Resulting avenues of research which may follow from Levenson prolegomenon must attempt to address what, if at all, is essentially "Jewish" about Levenson's Northern American "Modern Jewish Bible"; and if, indeed, this may be seen as an exclusively American phenomenon.

If his conclusions may be criticised for being a bit too "tidy," this is nevertheless a symptom of a presentation which is ultimately precise in organization and in style: Levenson should be congratulated for providing an access to modern Jewish approaches to the Bible; his synthesis of the scholarship and contextualization of this within temporal and locative boundaries will no doubt become essential reading for those attempting to get to grips with Jewish biblical scholarship. 